\title{
Progressive tremors, paresis and a sudden locked-in state
}

\author{
Nimish Sethiya, ${ }^{1}$ Arjun Maitra, ${ }^{2}$ Saugat Banerjee, ${ }^{1}$ Prashant Puraskar, ${ }^{1}$ Satish Pathak, ${ }^{3}$ Sushil Jindal, \\ Rakesh Biswas ${ }^{1}$
}

${ }^{1}$ Department of Medicine, People's College of Medical Sciences, Bhopal, India
${ }^{2}$ Department of Physiology, People's College of Medical Sciences, Bhopal, India
${ }^{3}$ Department of Radiology, People's College of Medical Sciences, Bhopal, India

Correspondence to Rakesh Biswas, rakesh7biswas@gmail.com

\section{DESCRIPTION}

A 37-year-old man developed low grade fever during January 2007 for which he received symptomatic treatment following which he gradually noticed a tremor of his left hand that made it difficult for him to write and even to put his signature. The tremors gradually progressed to his arms and trunk and he also developed a nodding movement in his head. There was progressive slowness in walking with a tendency to fall on either side. On examination in April 2007, he was noted to have a low frequency tremor at rest varying with posture and goal-directed activity suggestive of rubral tremor. His limb power at this time was normal. A cerebrospinal fluid examination was also normal and a MRI revealed signal hyperintensities in the mid brain tegmentum (figure 1) and hypodensities on the thalami on a subsequent CT head (figure 2). He was put on propranolol, tetrabenazine and clonazepam for his tremors but his symptoms kept progressing with gradual development of quadriparesis.

He was brought to us in November 2008 with a history of sudden loss of consciousness. We initially thought he was comatose with a blank stare but his relative alerted us to the fact that he was moving his eyelids and seemed to be conscious. We found that he had quadriplegia with near complete cranial nerve paralysis and preserved upper eyelid movement (video 1).

Video 1 Quadriplegia with near complete cranial nerve paralysis and preserved upper eyelid movement 10.1136/bcr.02.2009.1621v1

Rubral tremor (the term rubral is derived from its prior described association with lesions around the red nucleus in the midbrain tegmentum) is characterised by a slow coarse tremor at rest that is exacerbated by postural adjustments



Figure 1 MRI revealed signal hyperintensities in the mid brain tegmentum 


\section{BMJ Case Reports}

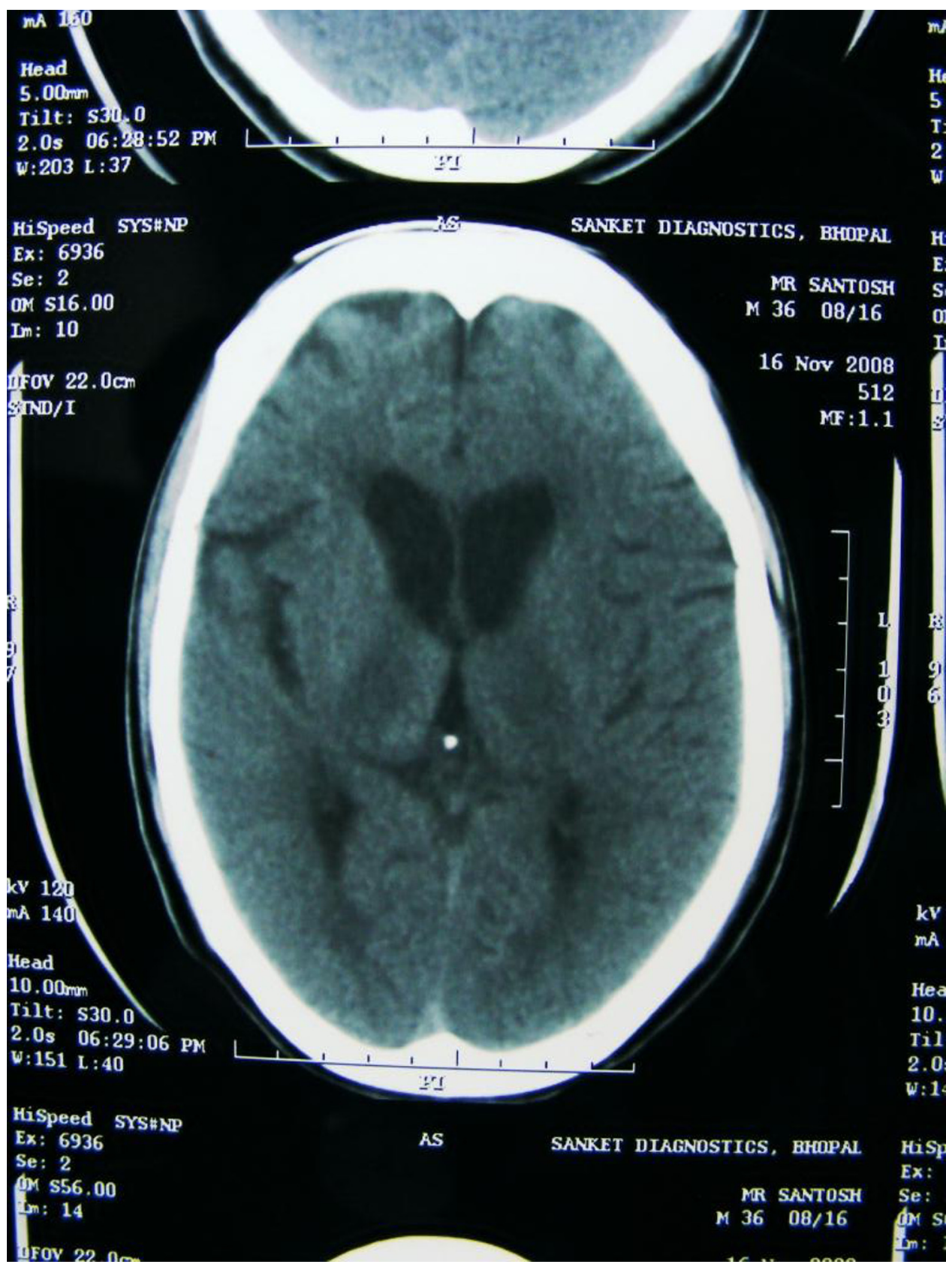

Figure 2 CT head scan showing bilateral thalamic hypodensities.

and by guided voluntary movements. Lesions of the superior cerebellar peduncle, midbrain tegmentum or posterior part of the thalamus may cause this peculiar tremor (and it is probable that lesions of the red nucleus itself are not crucial for its production). ${ }^{1}$ Our patient had demonstrable lesions in the midbrain tegmentum on MRI (figure 1), along with restricted diffusion on diffusion weighted imaging, and hypondensities in the thalami on the CT head scan (figure 2) suggestive of myelinolysis.

Anarthria in locked-in syndrome is due to bilateral facioglosso-pharyngo-laryngeal paralysis, which also causes dysphagia and limits the use of facial expression in communication. ${ }^{2}$

Over the next few weeks our patient gradually recovered minimal power with ability to form sounds and even verba- lise utterances (that could be understood by family members with great difficulty). He was discharged and later admitted to a nursing home with respiratory distress where he died. Autopsy was not done. Pulmonary complications are the leading cause of death in locked-in syndrome'. ${ }^{2}$

Acknowledgements To all involved in caring for this patient.

Competing interests None.

Patient consent Obtained.

\section{REFERENCES}

1. Berkovic SF, Bladin PF. Rubral tremor: clinical features and treatment of three cases. Clin Exp Neurol 1984;20:119-28.

2. Smith E, Delargy M. Locked-in syndrome. BMJ 2005;330:406-9. 


\section{BMJ Case Reports}

This pdf has been created automatically from the final edited text and images.

Copyright 2010 BMJ Publishing Group. All rights reserved. For permission to reuse any of this content visit http://group.bmj.com/group/rights-licensing/permissions.

BMJ Case Report Fellows may re-use this article for personal use and teaching without any further permission.

Please cite this article as follows (you will need to access the article online to obtain the date of publication).

Sethiya N, Maitra A, Banerjee S, Puraskar P, Pathak S, Jindal S, Biswas R. Progressive tremors, paresis and a sudden locked-in state. BMJ Case Reports 2010; 10.1136/bcr.02.2009.1621, date of publication

Become a Fellow of BMJ Case Reports today and you can:

- Submit as many cases as you like

- Enjoy fast sympathetic peer review and rapid publication of accepted articles

Access all the published articles

Re-use any of the published material for personal use and teaching without further permission

For information on Institutional Fellowships contact consortiasales@bmjgroup.com

Visit casereports.bmj.com for more articles like this and to become a Fellow 